\title{
LACERDA'S CHROMOGRAPHS (1930s-1950s): THE CIRCULATION AND APPROPRIATION OF KNOWLEDGE IN EUROPE AND THE AMERICAS
}

\author{
Quintino Lopes ${ }^{1}$, George Brock-Nannestad ${ }^{2}$ \\ ${ }^{1}$ Institute of Contemporary History - NOVA University of Lisbon; University of Évora, \\ Portugal \\ ${ }^{2}$ Copenhagen, Denmark \\ quintinolopes1@gmail.com
}

\begin{abstract}
From the 1930s to the early 1950s, chromography, a technique invented and developed by Armando de Lacerda, constituted an advanced method of investigation in the field of Phonetics which overcame the limitations of kymography, the method predominantly used in Experimental Phonetics laboratories during the period. The new technique was first used by Lacerda in collaboration with Paul Menzerath in Bonn, its use later spreading to Portugal and Brazil. The existence of the most advanced chromographic equipment at the University of Coimbra Experimental Phonetics Laboratory since 1936 explains why Portugal became a global centre for Phonetics research and remained such up until the 1950s, attracting numerous scientists from abroad who, under the supervision of its head, Armando de Lacerda, received specialist training in the use of chromography. Later, the technique was used at the University of Bahia, where Lacerda and Nelson Rossi established the first Experimental Phonetics laboratory in South America in 1956-57, and where the first work on linguistic geography of Brazil, entitled Atlas Prévio dos Falares Baianos, was produced.
\end{abstract}

Keywords: History of Experimental Phonetics; Chromography; Armando de Lacerda; circulation of knowledge

\section{Introduction}

The aim of this chapter is to provide a contribution to increasing our knowledge about the development of Experimental Phonetics. In contrast with the field of Linguistics as a whole, which has a long historiographical tradition, there are comparatively few studies focusing on the development and importance of the techniques of Experimental Phonetics, theories and instruments developed in the field, and the institutions and actors involved [1].

We firstly provide a background to the history of instruments used in the field of Phonetics before focusing on chromographs. We reconstruct the path followed by the instruments invented and developed in the 1930s by Portuguese phonetician Armando de Lacerda, and examine the following questions: where these instruments were first used; for what purpose; what the equipment consisted of; how it worked; where was knowledge about its existence circulated; who appropriated such knowledge; what its impact was on the development of Experimental Phonetics in the first half of the $20^{\text {th }}$ century; how far this led to the international circulation of scientists.

In geographical terms, our focus is on three research facilities equipped with chromographs: the University of Bonn Phonetics Institute, and the Experimental Phonetics laboratories of the universities of Coimbra in Portugal and São Salvador da Bahia in Brazil. By analysing links and exchanges between the three institutions, we seek to revive the memory in the field of historiography of the important role played by 
chromography and the relationship it established between researchers from a range of countries in different continents.

\section{The History of Experimental Phonetics Instruments: some considerations}

Experimental Phonetics is the term used for describing the use of equipment or apparatus with a view to enhancing and quantifying the sensory perception of spoken language, and an impression of its history is required in order to understand the contribution of individual researchers in the field.

The development of recording or registering instruments is in itself fascinating and has been dealt with in depth by V. J. Phillips in his book Waveforms [2]; however, their specific application in the field of Phonetics has not been covered. Three major accounts of the history of Experimental Phonetics are available: two books based on a collection of relevant equipment at the University of Dresden [3, 4], the proceedings of a conference [5], and Michael Ashby's dissertation on Experimental Phonetics at University College London [6], which covers its development in the UK. Furthermore, the linguist and phonetician Göran Hammarström has made an unpublished paper available to the authors, because it was considered important to have the views of a professional in this particular field, rather than the authors' look-in from the outside.

There follows a transcription of much of this unpublished paper:

«What can be considered as a first period of Experimental, also and better called instrumental, Phonetics begins with Jean Rousselot establishing a Phonetics laboratory in 1889 in Paris [5: 91-100]. This innovation was adopted by many European universities, but only by some universities in other parts of the world. Up to about 1950 the speech sounds were mainly investigated by kymography and palatography. Both were cumbersome techniques, and the results were not of the highest order. The kymograph showed the wave as a line traced by a stylus on sooted paper. The stylus also showed the airflow to some extent. It jumped up at the plosive phase of stop consonants. Most work concerned the duration of vowels and consonants. There was little regard for the difficulty of delimiting sounds that are coarticulated or that change gradually one into the other, but the results are on the whole valid. To make the stylus produce a good trace, or a trace at all, one had to say the sounds into the funnel held in front of the mouth in an unnaturally loud and clear way, which somewhat limits the adequacy of the results. It was normal that one looked at the just made kymogram to judge its quality. If it did not look good, it was discarded. Unfortunately a good kymogram could then be discarded if the picture did not correspond to the phonetician's idea of the sound.

In order to avoid the problem of the friction of the stylus against the sooted paper, which could influence the picture of the tracing, Lacerda constructed in the 1930s in Coimbra an instrument he called chromograph that used an ink jet on white paper [7]. The same procedure was later used in Siemens - Elema's mingograph. Another technically advanced instrument was the (cathode-ray) oscilloscope, which as oscillograph could show the sound wave on paper. Like the mingograph these instruments were known but not as much used as the kymograph by the early phoneticians.

E.A. Meyer constructed a device for measuring on the kymograms what was, and still is, wrongly called pitch. It could be used in studies of intonation. The device produced a curve in Hertz (which refers to fundamental frequency, not to pitch). Lacerda constructed a similar device that he called the tonometric triangle to be used on the tracings of his chromograph [7]. 
Palatography was the most used and best known technique to study articulation. One obtained pictures of where the tongue touches the palate in two ways. Either the palate was sprayed with carbon dust and the tongue removed it where it touched the palate, or the tongue was painted with black liquid and made an imprint on the palate. One could use a mirror and a camera to obtain a picture of the imprint. Another technique was to construct an artificial palate of thin flexible metal, which was introduced into the mouth and on which the imprint was made. It was then taken out and the imprint was drawn. The form of the lips could be easily photographed. An xray picture could be taken of the typical articulatory position of a vowel or a consonant, or an x-ray film could be taken of the articulation of segments of speech. The use of these important possibilities was limited probably because the phonetics laboratory did not have the equipment and because x-rays are dangerous.

One can consider that the second period of Phonetics begins about 1950 because new instruments came into use. This happened immediately in some laboratories and more slowly in others. Excellent sound could be recorded by magnetophones, which later were just called tape recorders. The rather primitive cylindrical Edison phonograph had had some use in the earliest laboratories. The gramophone with disk and turntable was available since the establishment of practically all laboratories. Its sound was good but the recording was complicated and the equipment was not available in the laboratory so it was not used. New electronic pitchmeters and intensitymeters could show the curve of the fundamental frequency in Hertz and the intensity curve in decibels respectively.

The really revolutionary instrument was, however, the sonagraph [sound spectrograph], which was available from about 1950. It was now possible to analyse the acoustic picture of what one pronounced and heard as vowels, consonants, coarticulations and suprasegmentals. As one well knew the correspondences between acoustic and articulatory details, the acoustic results were at the same time articulatory results. To use the new instruments one needed a technician. The sonagraph in particular required much attention to function perfectly. The technician also needed to be in attendance when the students used the instruments in their work. Less progressive phoneticians continued to work with the kymograph till at least towards the end of the 1950s» [8].

Thus, the equipping of the Coimbra Phonetics Laboratory with chromographs, documented from its foundation in 1936, coincided with a new stage in the history of Experimental Phonetics in the first half of the $20^{\text {th }}$ century, and it is important that this should be recognised.

\section{Chromography: from the local context to the global}

Founded in 1936 and directed by Armando de Lacerda, the University of Coimbra Experimental Phonetics Laboratory was regarded in the early fifties by several members of the international academic community as the most advanced Experimental Phonetics laboratory in Europe. There is evidence of its excellent reputation, based on the high standard of the facilities at the laboratory, in the writing of Pierre Van Bever, for example, who published the following comment in Revue belge de philologie et d'histoire in 1953: "Le prof. Lacerda est lui-même l'inventeur de nombreux appareils de mesure et d'enregistrement, et son laboratoire, fondé en 1936, est sans doute le meilleur d'Europe" [9].

At the same time, in a similar vein, although not so peremptorily, Francis Millet Rogers (Harvard University) stated: 
«In the Faculty of Letters of the University of Coimbra is a superbly installed and very well equipped Laboratory of Experimental Phonetics. [...] Great credit is due the Portuguese Ministry of National Education, the Instituto de Alta Cultura, and administrative officials and professors of the University not only for having supported the founding of the Laboratory in 1936 but also for having so generously provided excellent space for it in the recently constructed new building of the Faculty of Letters. Credit is also due them, and the Laboratory's genial Director, Dr. Armando de Lacerda» [10].

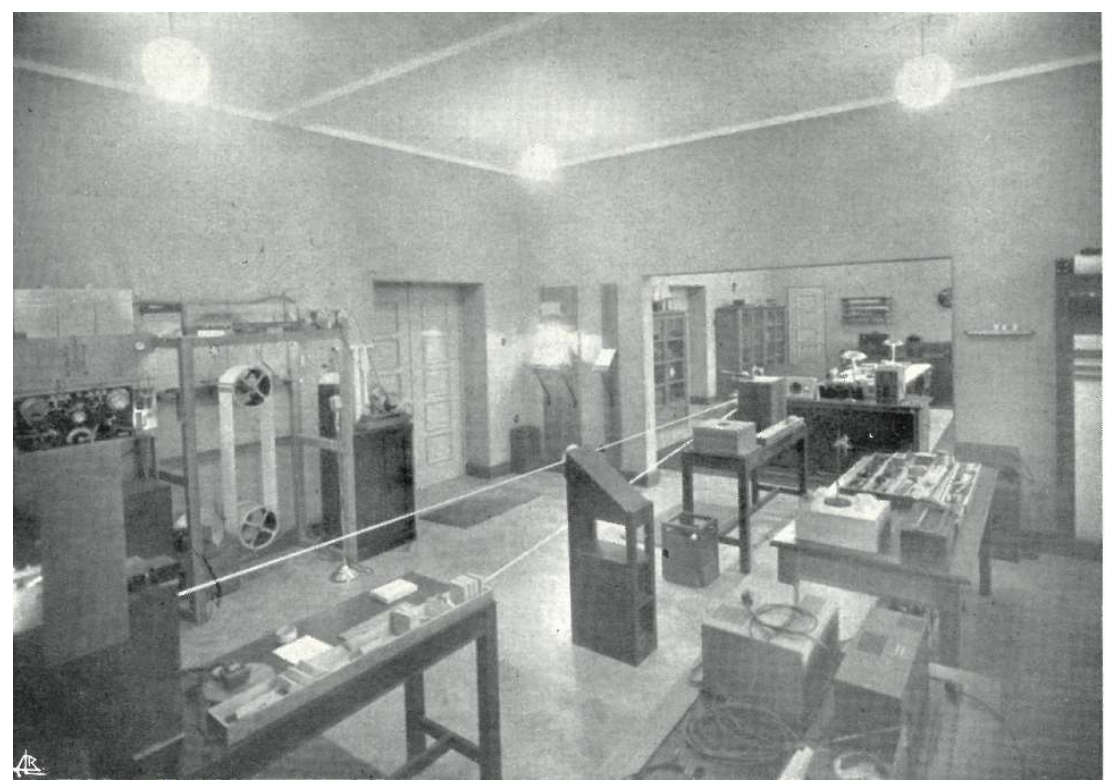

Figure 1. The photograph shows two of the ten rooms that the Coimbra Phonetics Laboratory occupied in 1952 in the new Faculty of Letters building, with "an endless paper strip emerging from a horizontal projection chromographic recorder" in the foreground. (Biblioteca Nacional de Portugal).

In 1979, about a quarter of a century after this photographic record was produced and the opinions above recorded, in the absence of a successor to Lacerda as head of the facility, the Coimbra Phonetics Laboratory was closed down. The same year, as the memory of the laboratory began to fade, its first and only head retained the distinction of honorary member of the Permanent Council for the Organization of International Congresses of Phonetic Sciences, along with Roman Jakobson (Cambridge, USA) and Eberhard Zwirner (Cologne, Federal Republic of Germany).

This distinction was bestowed personally on Lacerda at the $4^{\text {th }}$ International Congress of Phonetic Sciences, held in Helsinki in 1961, during the course of a career launched during Germany's Weimar Republic, referred to by his disciple Göran Hammarström, founder in 1955 of the University of Uppsala Department of Phonetics, in the following terms:

«When the young Lacerda decided to study abroad, he went to Hamburg where the highly reputed Giulio Panconcelli-Calzia was working. There he constructed instruments to measure articulatory movements but, as he told me, PanconcelliCalzia did not give him the praise he had hoped for. Therefore he left for Bonn where Menzerath was the head of a phonetics department that would overtake Hamburg as the most important place to study phonetics in Germany. Menzerath appreciated Lacerda's work and suggested that they should write a book together. According to what Lacerda told me he wondered if this was a good idea because the suggested topic, coarticulation, had already been treated by other authors. But Menzerath had no hesitations so one of the most important books in phonetics was written: 
Koartikulation, Steuerung und Lautabgrenzung (1933). It would be obvious that the elegant formulations and the general picture is Menzerath's but Lacerda's basic ideas and results are crucial. The order of the names of the authors of the book, Menzerath - Lacerda, is the one which one expects when an older professor has collaborated with a younger disciple. As things are, one sometimes sees authors quoting Menzerath's ideas on coarticulation. This is not acceptable because Lacerda is perhaps the more important author» [11: 90].

In addition to his pioneering studies on the co-articulation and segmentation of speech sounds, as mentioned above, Armando de Lacerda also stands out for his creativity in inventing and developing new instruments. Among the various devices he designed during his time in Hamburg and Bonn is the polychromograph.

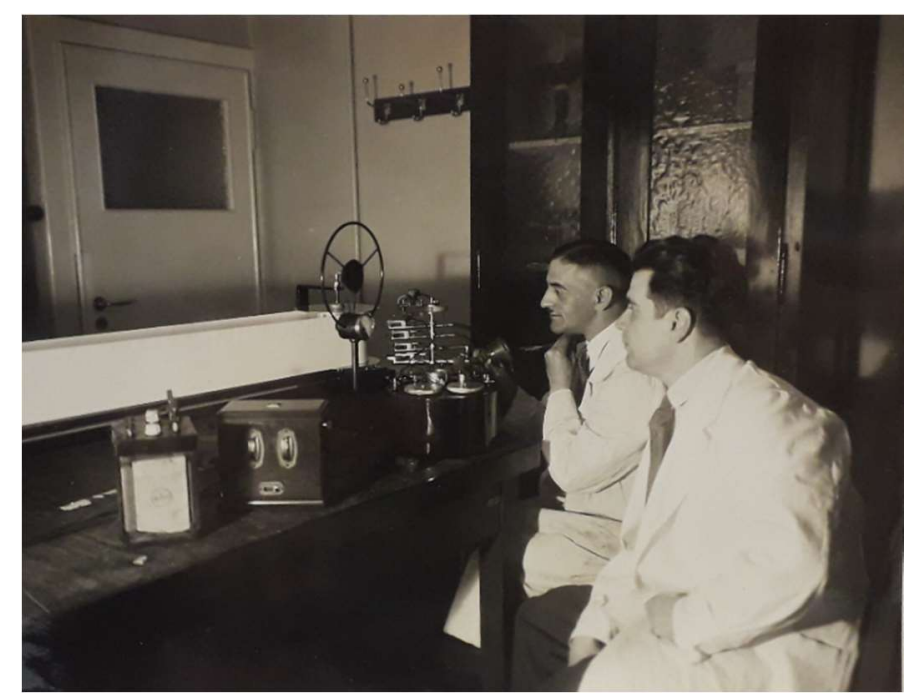

Figure 2. The photograph shows Armando de Lacerda, and on the left, K. Weitkuss, a laboratory assistant at the University of Bonn Institute of Phonetics, operating a polychromograph (1932). (Arquivo do Camões, Instituto da Cooperação e da Língua, I.P., Caixa 1337, Processo 3).

The polychromograph had a mouthpiece and recorded speech sounds and mouth movements on a strip of paper with a fine jet of ink, thus resolving the problem of stylus friction with the kymograph. Lacerda developed three methods of deflecting this jet. One was direct vibration from the tambour registrateur - this avoided all friction and the influence of the weight of the lever, another was sideways blowing on the jet (the most direct influence without electronic amplification), and the third was electromagnetic vibration of the nozzle. The electromagnetic solution meant that amplifiers were involved.

The development of the Lacerda polychromograph marked the introduction of chromography as a new research method and the inventor received funding of 11,000 escudos from the Portuguese state for its construction, provided that it was to be used at an Experimental Phonetics laboratory to be established in Portugal.

Before this happened, chromography was initially used in Germany. In 1932, Armando de Lacerda was invited by Eberhard Zwirner to use chromography with the "Ketterer system" at the Kaiser-Wilhelm Institut für Hirnforschung in Berlin. As early as 1936, signalling the growing international acceptance of chromography, Lacerda noted: "In a new paper in Dutch, Professor Theodor Baader from Nijmegen cites my chromographic method as one of the greatest advances in Experimental Phonetics" [12].

Recognising the importance of the new method, in 1933 Paul Menzerath invited the Portuguese phonetician to teach an 'Introduction to Chromography' course at the Institute of Phonetics at the University of Bonn. 


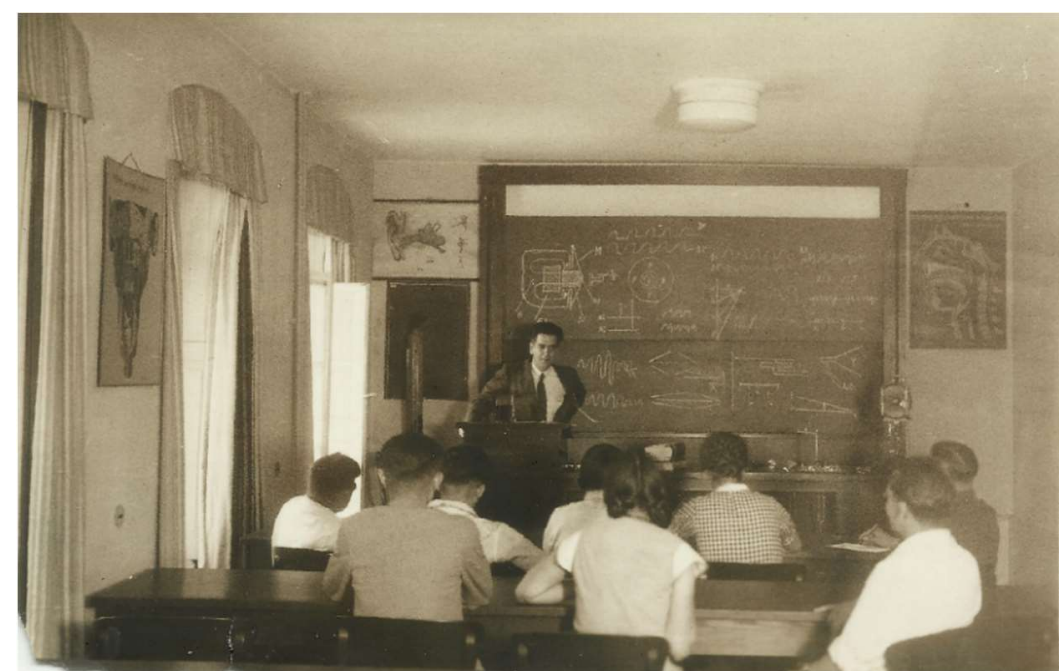

Figure 3. The 'Introduction to Chromography' course taught by Lacerda was targeted at professors and $\mathrm{PhD}$ students of the University of Bonn. (Zamora Canellada Family Archive).

The course led to the use of chromography in $\mathrm{PhD}$ studies at the University of Bonn applied to phenomena of tonal variation in the Chinese and English languages. An example of this in the case of Chinese was the PhD dissertation of Schu-Yün ChwangWang (Bonn, 1935), whose phonograms were recorded with the use of chromography by Armando de Lacerda himself.

Returning to Portugal in July 1933, Lacerda set up the first Portuguese Experimental Phonetics laboratory at the University of Coimbra [13]. The laboratory opened in 1936, and its head stated that it would boast the most advanced chromographs, which explains the attraction it held for many scientists from abroad from the 1930s to the 1950s, including the likes of Peter Strevens (then head of the Department of Phonetics of University College of the Gold Coast), Francis Millet Rogers (Harvard University), Göran Hammarström (University of Uppsala), J. H. Uldall (University of Edinburgh) and Nelson Rossi (University of San Salvador da Bahia), among many others.

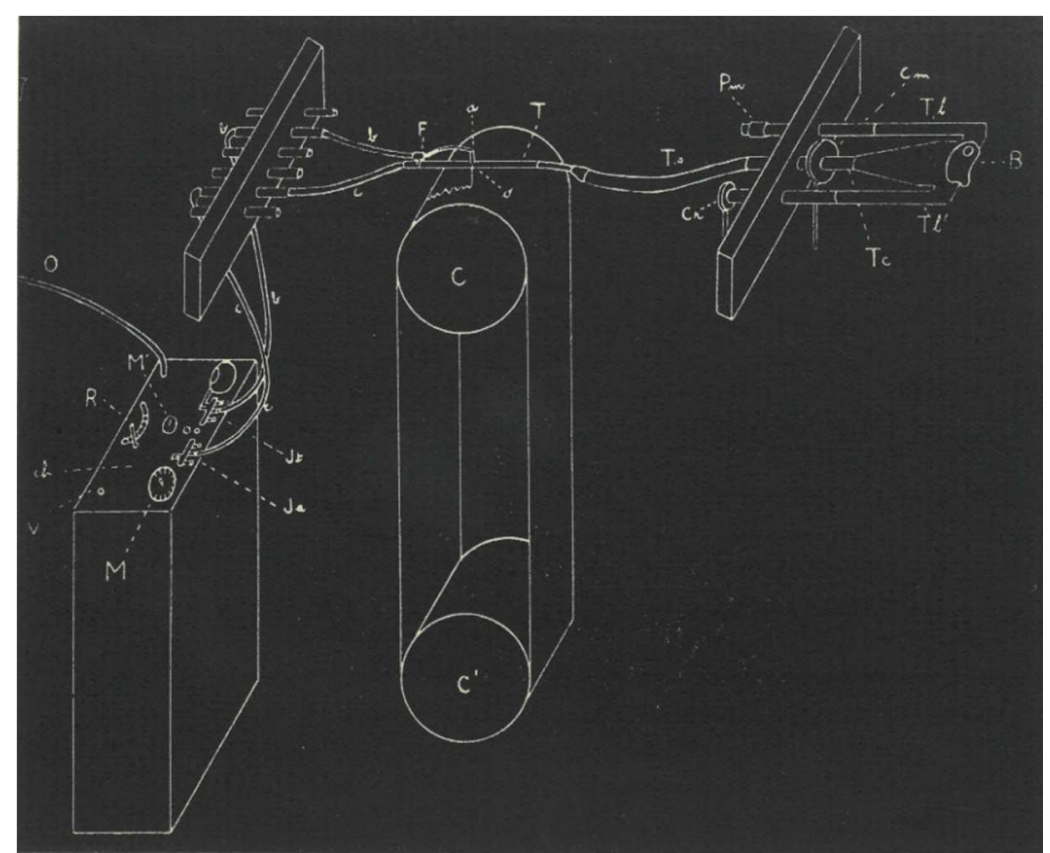

Figure 4. Technical drawing of the chromograph at the Coimbra laboratory in 1939. (Biblioteca do Laboratório de Fonética. Faculdade de Letras de Coimbra). 
The main components of the chromograph can be seen in the drawing:

1) Sound recording devices, with the mouthpiece on the right (B). Made of metal plate, the mouthpiece was thick enough not to vibrate and much bigger than that used in kymography. The front part is oval in shape and the rear is conical, while the outside edges of the front part are bevelled in order to enable a good fit on the face. The space at the front is connected to two lateral pieces of tubing ( $\mathrm{Tl} \mathrm{e} \mathrm{Tl}^{\prime}$ ), the rear extending into the central tube $(\mathrm{Tc})$.

2) Chromographic projectors. Speech sounds are recorded by injecting coloured ink onto a paper strip running below. They are connected to the central tube (Tc) by means of a tube (Ts) and are fed ink, at the other end, through a rubber tube (b), next to the tube which feeds in air (c).

3) Pressure reservoirs and regulators. Feeding tubes (b and c) communicate with two sets of taps (Jt and Ja), for feeding ink and air, fixed on a metal plate (ch), which rests on a support table (Figure 6). Below the metal plate there are two reservoirs. A regulator (R) controls a tap which coordinates the flow from these reservoirs. A manometer (M) indicates air pressure in the ink reservoir and another manometer (M') indicates air pressure in the other (compensatory) reservoir, which is connected to a bottle of compressed air by means of a tube $(\mathrm{O})$ (Figure 5).

4) Recording cylinder $(\mathrm{C})$ powered by an $\mathrm{a} / \mathrm{c}$ motor.

5) Auxiliary cylinder (C'), whose distance from recording cylinder can be regulated, allowing for the use of strips of paper [19: 8-18].

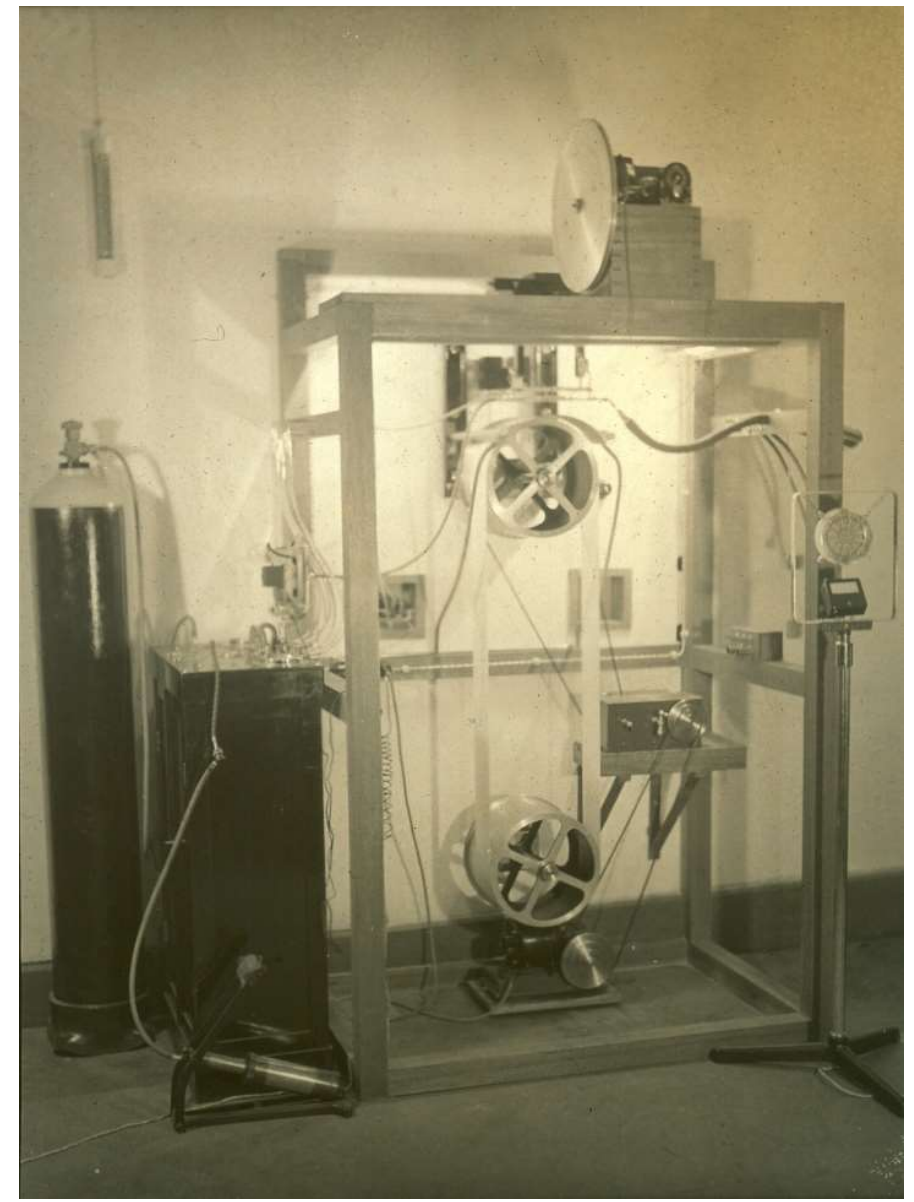

Figure 5. The chromograph at the Coimbra laboratory in 1939. (Museu da Ciência da Universidade de Coimbra). 
Demonstrating how chromographs were decisive for many linguists electing Coimbra as their choice of university for receiving specialist Phonetics training in the first half of the $20^{\text {th }}$ century, there is the letter that Lacerda sent to Eberhard Zwirner in 1940. In it, regarding the work he published jointly with Francis M. Rogers as a result of their collaboration at the Coimbra Phonetics Laboratory in 1939, the Portuguese phonetician noted:

«The work [...] was made with the collaboration of Mr. Francis Millet Rogers, [...] of the Graduate School of Arts and Sciences, Harvard University, who has been studying with me this year in my laboratory in order to obtain a first-hand knowledge of the latest developments in my chromographic method» [14].

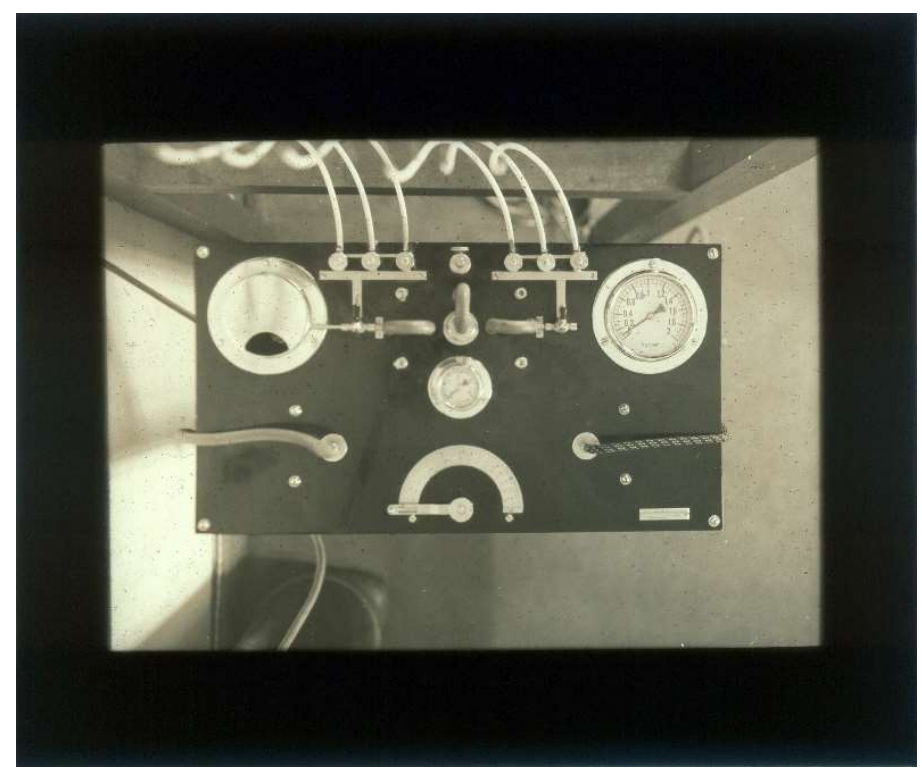

Figure 6. Detail of a chromograph used by Francis M. Rogers at the Coimbra Phonetics Laboratory, where he underwent specialist training for four months in 1939. (Museu da Ciência da Universidade de Coimbra).

On the impact on scientists' academic careers as a result of using chromographs in their work, we have the response given by Georges Straka, head of the Institute of Phonetics at the University of Strasbourg, to the head of the Uppsala University Faculty of Letters when asked about the scientific skills of Göran Hammarström: "His research on the length of phonemes in Swedish [...] is of great general interest to those in the field of Linguistics. The results achieved far exceed those of previous researchers, thanks to the excellent chromographic method used by Mr. Hammarström" [15]. When one considers that this response in 1957 was decisive with regard to the advancement of Hammarström's academic career - he began as a $\mathrm{PhD}$ student at the Coimbra Phonetics Laboratory, later becoming the first full professor of Linguistics in Australia, at Monash University - the importance of conducting research using the chromograph at Coimbra becomes clear.

In the context of the development of the chromograph by Lacerda, Hammarström in 1952 published a work entitled Le chromographe et le triangle tonométrique de Lacerda [16]. Its publication, in French, illustrated with technical drawings, led to several requests from laboratories abroad for chromographic equipment. In this regard, what happened in Spain in the post-World War II period should be mentioned: after the failure of the Consejo Superior de Investigaciones Científicas - Higher Council for Scientific Research - to establish a Phonetics laboratory at the University of Barcelona, to be equipped with Armando de Lacerda's instruments, in 1958 Manuel Companys, who had previously 
carried out research under the supervision of Lacerda at Coimbra, reaffirmed his intention to establish the use of chromography at a Phonetics laboratory to be set up in Barcelona: «[...] it seems that we will be able to set up a laboratory in Barcelona next year, for which I will be responsible. Unfortunately, very little money will be available for the project. I plan to set up units dedicated to the following: HiFi recording [...]; spectrography $[\ldots]$; chromography; recording and transcription $[\ldots]$; surveys $[\ldots]$; photography and macrophotography [...]. I would also like a speech-stretcher [...]. Unfortunately, the spectrographic equipment and probably the HiFi equipment [...] has to be dispensed with, but the last thing I will give up is our chromographic equipment, which we can do a lot with» [17].

In the 1950s, on the other side of the Atlantic, another university achieved what apparently did not come to fruition in Spain. As part of a concerted policy for the development of Experimental Phonetics in Brazil, Nelson Rossi of the University of São Salvador da Bahia obtained funding for undergoing specialist training at the Coimbra Phonetics Laboratory in 1954-55. After completing his internship working under Lacerda's supervision, he later became an intern at the Institut de Phonétique in Paris. Rossi then returned to São Salvador and the Portuguese phonetician was invited by the rector of the University of Bahia, Edgard Santos, to come to Bahia and set up what would be the first Experimental Phonetics laboratory in South America [7].

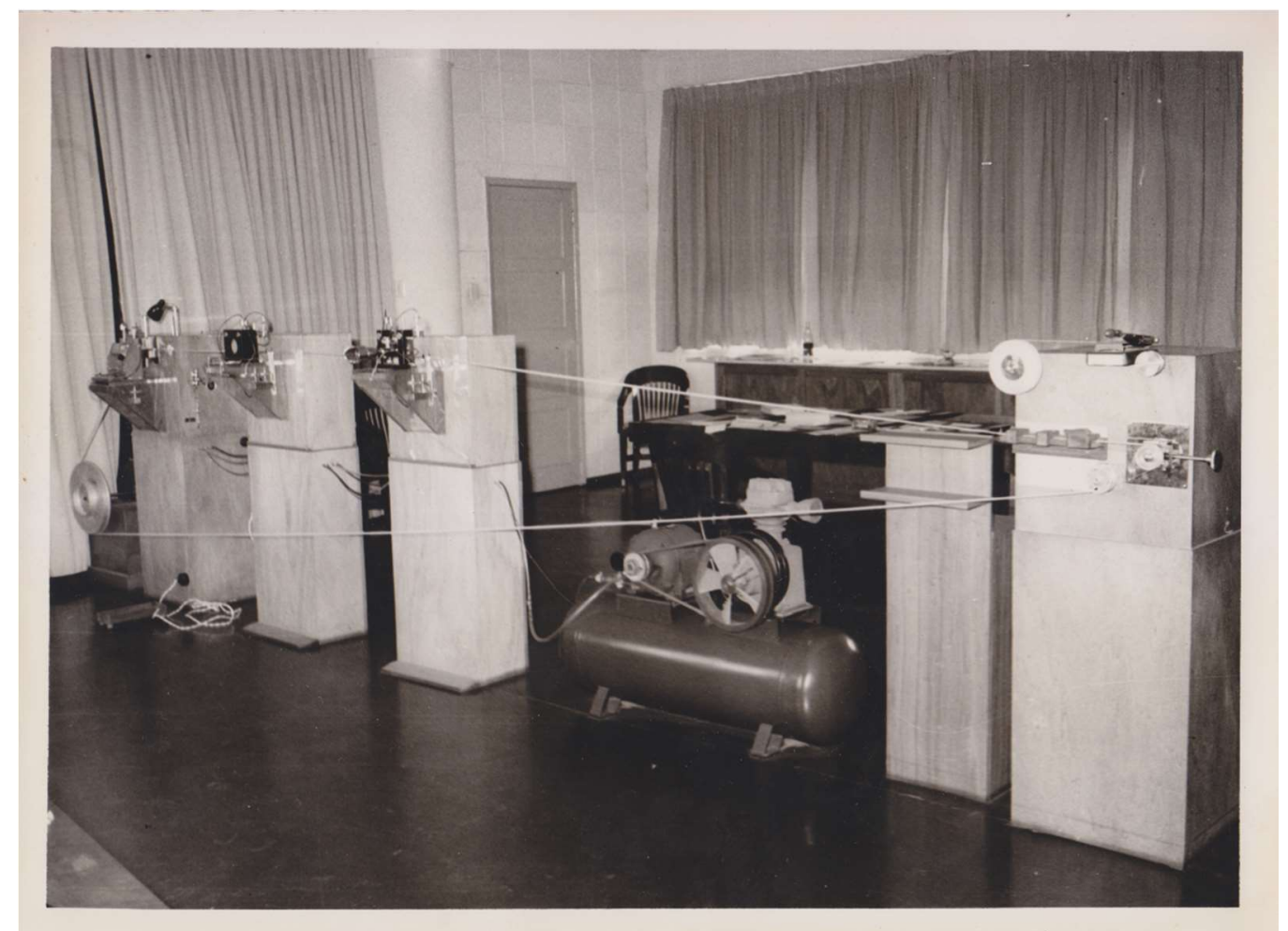

Figure 7. Equipped with chromographs, the University of Bahia Experimental Phonetics Laboratory carried out measurements and analyses, one of its main roles, using the techniques of chromography and tonometry, based on the model used at the Coimbra Phonetics Laboratory (Arquivo Familiar Paulo de Lacerda - Paulo de Lacerda Family Archive).

Highlighting the importance of the role of Lacerda and the research techniques he developed, associated with the establishment and operations of the Brazilian laboratory, Nelson Rossi, its head, stated:

"Our aim is that the Phonetics Laboratory of the University of Bahia Faculty of Philosophy should work as closely as possible with similar bodies all over the world, 
and especially Coimbra, to exchange knowledge and ideas, not only due to the fact that the work of the two laboratories focuses on what is basically the same language [...] but above all because the Bahia laboratory was inspired by and uses the models and methods devised by the true founder of both institutions: Armando de Lacerda» [18: 6].

While Armando de Lacerda also set up another Experimental Phonetics laboratory at Colégio Pedro II in Rio de Janeiro in 1957-58, which was also equipped with his chromographic instruments, the laboratory in Bahia achieved greater standing in the field of Linguistics and Phonetics in Brazil. For example, it was the latter that produced, from 1960 to 1963, the first linguistic atlas of Brazil, entitled Atlas Prévio dos Falares Baianos, produced by Rossi and his collaborators and based on techniques of phonetic transcription appropriated from Armando de Lacerda and Göran Hammarström [7].

\section{Conclusion}

The history of scientific instruments shows that up until the early 1950s the kymograph and the palatograph constituted basic items of equipment at Experimental Phonetics laboratories around the world. From then on, the most advanced research facilities in this field of linguistics were equipped with the sound spectrograph. We seek to add a new chapter in the history of Experimental Phonetics by highlighting the importance of the polychromograph, invented by Armando de Lacerda in Bonn in 1932. Later, in Portugal, Lacerda used only one channel (for the speech waveform) and termed his instrument simply chromograph.

These instruments were not as much used as the kymograph. As the cost of production of instruments involving sound amplification fell, interest in the chromograph waned, and one may speculate that if it had been invented 10 years earlier it might have become standard equipment, replacing the kymograph and several types of amplified instruments until the cost of the sound spectrograph fell to a level which enabled it to be purchased by phonetics laboratories.

Despite this, until the appearance and dissemination of the sound spectrograph, the technical advance that the chromograph represented in comparison with the kymograph meant that laboratories that were equipped with the former boasted better facilities. Thus, in terms of history of Experimental Phonetics, and the history of science in general, it is interesting to note that Portugal, as it possessed an Experimental Phonetics laboratory equipped with the most advanced chromographs, had from 1936 to the early 1950s what came to be regarded by a number of influential linguists of the time as the best facility of its kind in Europe.

Some of the other laboratories in Europe and South America either sought to acquire chromographs or were equipped with such instruments during the period from the 1930s to the 1950s. Among these were the Experimental Phonetics Laboratory of the University of São Salvador da Bahia, the first laboratory of its kind in South America, whose work further demonstrates how the use of chromography spread outside Europe.

\section{Acknowledgements}

In 2019, following the $3^{\text {rd }}$ International Workshop on the History of Speech Communication Research held in Vienna, I was contacted by the late George BrockNannestad, who showed interest in studying the instruments that Armando de Lacerda devised for Experimental Phonetics. We soon decided to jointly publish a paper on the subject. Unfortunately, he passed away in December 2020 before this work was completed. As a consequence of this irreparable loss, any errors are the first author's responsibility. I am grateful for the privilege of having been able to collaborate with 
George Brock-Nannestad, and we also benefitted from the help and kindness of the late Göran Hammarström, who made available an unpublished paper of his. I am therefore grateful to Hammarström and would like to thank his daughter, Marika Hammarström, for giving her permission for it to be cited in the present chapter following the death of her father.

\section{Funding}

The Instituto de História Contemporânea (Institute of Contemporary History, University of Évora Unit) receives national funding from the FCT - Fundação para a Ciência e a Tecnologia under project UIDB/04209/2020. This research was also supported by the private company Ferraz de Lacerda, Lda.

\section{References}

[1] KOERNER, E. F. K.: Historiography of Phonetics: the State of the Art. Journal of the International Phonetic Association, 23 (1), pp. 1-12, 1993.

[2] PhILLIPS, V. J.: Waveforms: A History of Early Oscillography. Bristol: IOP Publishing Ltd. Adam Hilger, 1987.

[3] MEHNERT, D.: Historische phonetische Geräte, Katalog der historischen akustischphonetischen Sammlung (HAPS) der TU Dresden, erster Teil. Dresden: TUD Press, 2012.

[4] Mehnert, D.; PÉtursson, M. \& Hoffmann, R.: Experimentalphonetik in Europa. Institute, Wissenschaftler, Leistungen Ende des 19./Anfang des 20. Jahrhunderts. Dresden: TUD Press, 2016.

[5] Bö̈, L.-J. \& VILLAIN, C.-E. (Eds.): Un siècle de phonétique expérimentale. Fondation et éléments de développement. Lyon: ENS Éditions, 2010.

[6] AshBY, M. G.: Experimental phonetics in Britain, 1890-1940. Unpublished doctoral dissertation, University of Oxford, 2016. Available at https://ora.ox.ac.uk/objects/uuid:d8bbffae-8a4e-478e-ba650f5a5bbd66e1/download file? safe filename=Ashby-DPhil2016.pdf\&file format $=$ application $\% 2$ Fpdf\&type of work $=$ Thesis

[7] LOPES, Q.: The Global Periphery: Armando de Lacerda and the Coimbra Experimental Phonetics Laboratory (1936-1979). Lisbon: Caleidoscópio, 2021.

[8] HammarströM, G.: Phonetics: aspects of its history. Unpublished notes. Quoted with permission. The bibliographic references mentioned in this transcription were added to the original by the authors.

[9] BEVER, P. V.: Chronique. Revue belge de philologie et d'histoire, 31 (1), pp. 206-369, 1953.

[10] ROGERS, F. M.: Review: Étude de phonétique auditive sur les parlers de l'Algarve. Romance Philology, 8 (4), pp. 284-299, 1955.

[11] HammarströM, G.: Memories of a linguist 1940-2010. Muenchen: Lincom Europa, 2012.

[12] Arquivo do Camões, Instituto da Cooperação e da Língua, I.P. Caixa 1319, Processo 11, Documento 1.

[13] LOPES, Q. \& PEREIRA, E.: Armando de Lacerda and Experimental Phonetics in the inter-war period: scientific innovation and circulation between Portugal, Germany and Harvard. In: M. PUCHER, J. TROUVAIN \& C. LOZO (Eds.): Proceedings of the Third International Workshop on the History of Speech Communication Research. Dresden: TUD Press, pp. 95-104, 2019.

[14] Biblioteca do Laboratório de Fonética. Faculdade de Letras de Coimbra.

[15] Göran Hammarström Family Archive (letter dated 15th February 1957). 
[16] Hammarström, G.: Le chromographe et le triangle tonométrique de Lacerda. Coimbra: Laboratório de Fonética Experimental da Faculdade de Letras da Universidade de Coimbra, 1952.

[17] Göran Hammarström Family Archive (letter from Manuel Companys to Göran Hammarström dated 25th August 1958).

[18] Rossi, N.: Laboratório de Fonética na Bahia. Coimbra: Laboratório de Fonética Experimental da Faculdade de Letras da Universidade de Coimbra, 1958.

[19] LACERDA, A. \& ROGERS, F. M.: Sons dependentes da fricativa palatal áfona, em Português. Coimbra: Laboratório de Fonética Experimental da Faculdade de Letras da Universidade de Coimbra, 1939.
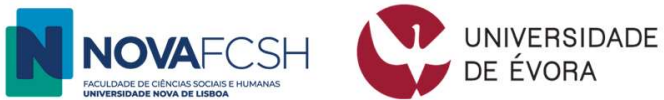